\title{
JUDICIAL ANALYSIS ON THE POSITION OF LEGAL OPINION (FATWA) OF INDONESIAN COUNCIL OF ULAMA' (MUI) IN STATUTORY REGULATION SYSTEM OF INDONESIA
}

\author{
By: \\ Pofrizal, Akhmad Muslih, Ardilafiza
}

\begin{abstract}
The purpose of this research is to investigate, understand, describe, analyze and get a picture of the legal position of MUI fatwas in the statutory regulation system in Indonesia based on Law No. 12 of 2011 on Making Rules and Hierarchy of Rules. The method used in this research is normative. The results show that MUI fatwas are not included in positive law and don't have permanent legal power based on Law No. 15 of 2019 on the Amendment to Law Number 12 of 2011 on Making Rules and Hierarchy of Rules, so it cannot be legally applied to all Indonesian people. Also, fatwas of MUI cannot be a legal instrument to enforce legal act or to become the basis for imposing criminal sanctions for those who violate the law. It can only become positive law if the substance is stipulated by the authorized state institutions into laws and regulations as it is outlined in Law No. 15 of 2019 on the Amendment to Law No.12 of 2011 on Making Rules and Hierarchy of Rules.
\end{abstract}

Keywords: Accountability, Corporate Crimes, Artificial Legal Subject 


\section{A. INTRODUCTION}

\section{Background}

The Islamic judiciary has developed and played its functions as an institution that solves the problems of Muslims in the positive legal system of Indonesia, namely the institution of Islamic Religious Justice. The first step after the independence of Indonesia taken by the government is to hand over the administration of Religious Justice from the Ministry of Justice to the Ministry of Religion through Government Regulation No. 05/SD/1946, as Law No. 190 of 1948 was issued in 1948 that its time of validity was determined by the Minister of Justice. The law includes the Religious Court into the General Court. ${ }^{1}$

Islam has shown its existence as it can adapt to all times and places. Allah shows his power through the various abilities possessed by humans, namely the experts in the fields of fiqh, hadith, social sciences, psychology, and other scientific fields. This diversity makes humans complement each other with their respective strengths and weaknesses, as humans receive and give. This diversity also gives humans the ability to understand law and obedience

${ }^{1}$ Amrullah Ahmad, Dimensi Hukum Islam Dalam Sistem Hukum Nasional, Gema Insani Pers, Jakarta, 1996, p. 6 to Allah SWT. This ability shows that humans need each other to solve their problems with help from the more capable ones. At the most, the response from the ulama' was considered very important in finding solutions to controversial problems that occurred, especially those related to Islamic affairs. The problem is that there is no clear basis in the Al-Qur'an or the Sunnah of the Prophet, so this condition requires scholars to find arguments that are in line with Islamic law to create solutions for the benefit of Muslims.

These are what become the basis for Muslim scholars in Indonesia to be collectively more motivated and have a desire to unite the movements and steps of the Muslim community to reach common ideals in the context of the sovereign of the Republic of Indonesia. These Muslim scholars formed a large institution with the authority to respond or determine attitudes toward controversial issues. This large institution is known as the Council of Indonesian Ulama' (MUI). Regarding attitude or response issued by the MUI, it is called a legal opinion (fatwa). MUI was established in Jakarta on 7th of Rajab 1395 H or 26th of July 1975 AD. ${ }^{2}$

2 M. Erfan Riadi, Kedudukan Fatwa Ditinjau Dari Hukum Islam Dan Hukum Positif (Analisis Yuridis Normatif), Jurnal Hukum 
The definition of fatwa according to syara' is explaining syara' law in a problem as an answer to a question, either it is coming from a party with clear identity or not, both individually and collectively. ${ }^{3}$ A fatwa is not either an easily-made legal decision or a baseless-made law. ${ }^{4}$

A fatwa issued by MUI is following its authority, in this case, MUI has the authority and territory, namely:

1. MUI has the authority to issue fatwas on religious issues in general, especially legal issues (figh) and aqeedah issues concerning the truth and purity of the faith of Indonesian Muslims;

2. MUI is authorized to issue a fatwa on such religious issues as mentioned in point (1) regarding Indonesian Muslims nationally or religious issues in one area that may extend to other areas;

3. Regarding the problem that has been solved by an MUI fatwa, the Regional MUI only has the right to implement it;

4. If due to certain factors the MUI fatwa as referred to in point (3) cannot be implemented, the Regional MUI may issue a different

http://ejournal.umm.ac.id/index.php/ulum/article/ viewFile/1305/1398, retrieved on $20^{\text {th }}$ of January 2019

Yusuf Qardhawi, Fatwa Antara Ketelitian Dan Kecerobohan, Gema Insani Press, Jakarta, 1997, p.5

${ }^{4}$ Ahyar A. Gayo," Kedudukan Fatwa MUI Dalam Upaya Mendorong Pelaksanaan Ekonomi Syariah", Penelitian Hukum Badan Pembinaan Hukum Nasional Kementerian Hukum Dan HAM Ri, 2011, p. 13. fatwa after consultation with the Central MUI;

5. Regarding the non-existing MUI fatwa Regional MUI has the authority to set fatwa(s);

6. Specifically on very Musykil and Sensitive issues before issuing a fatwa, the Regional MUI is expected to first consult with the Central MUI. $^{5}$

Based on the source of formal law that applies in the national legal system, there are five sources of law: statutory regulations, customs, judges' decisions (jurisprudence), treaties, and doctrines (legal expert opinion).

The order of the applied laws and regulations in Indonesia is regulated in Law No. 12 of 2011 on Making Rules. The hierarchy is explicitly regulated in Article 7 as the following:

(1). Types and hierarchy of Rules consists of:

a. Constitution of the Republic of Indonesia of 1945;

b. People's Consultative Council Decree;

c. Law/Government Regulation In Lieu of Law;

d. Government Regulation;

e. Presidential Regulation;

f. Province Regulation; and

g. Regency/Municipality Regulation.

(2). The power of Rules is in accordance with the hierarchy as intended in point (1).
${ }^{5}$ Ma'ruf Amin, dkk, Himpunan Fatwa Majelis Ulama Indonesia Sejak 1975, Erlangga, Jakarta, 2011, p. 7-8. 
Fatwas

have

unique

characteristics. These characteristics show that fatwas as legal products have different legal standing and powers between one Muslim country and another. This difference is influenced by the legal system, governance, and state administration adopted by the countries. Some countries place fatwas or fatwamaking institutions within the legal system and government structures, while others place them outside the legal system and government structures. This has implications for the position and strength of different fatwa laws for each country. The Fatwas or the fatwamaking institutions that are in the legal system or structure of a government have a more binding legal position and power than those outside the legal system and government. The State of Saudi Arabia, for example, specifically includes fatwas in Article 45 (forty-five) of the country's constitution which states "The source of fatwas in the kingdom of Saudi Arabia is the Book of Allah and the Sunnah of His Messenger. This system describes the organizational structure of senior scientists, their scientific studies, their attitudes, and their characteristics". 6 The Egyptian state has officially had the Daral-Ifta' (the office that issues fatwas since 1895 headed by the state's grand mufti. The Egyptian Fatwa Institute is one of the agencies under the Ministry of Justice". 7

Compared to Indonesia, the position of the legal system in the two Islamic countries, Saudi Arabia and Egypt is different. In Indonesia, fatwas are only considered as appeals, but on the other hand, some fatwas must be followed, such as sharia economic fatwa which is mandatory for Islamic banking. If sharia banking is not followed then MUI can give a warning and propose to the Financial Services Authority (OJK) to take action against this sharia banking. This shows an inconsistency of applicable MUI fatwas in Indonesia.

\section{Problems Identification}

The formulation of the issues raised in this research is: Judicial analysis on the position of legal opinion (fatwa) of Indonesian Council of Ulama' (MUI) in statutory regulation system of Indonesia?

\section{B. METHODOLOGY}

The method used in this research is qualitative. Qualitative research is research that uses a holistic approach that requires a variety of information to be analyzed so that certain aspects of

\footnotetext{
7 Noname Kedudukan Lembaga Fatwa Mesir" $\quad$ http://dar-alifta.org/Module. aspx?Name=aboutdar (retrieved on $10^{\text {th }}$ of October 2019)
} 
human attitudes can be understood. ${ }^{8}$ This type of legal research is normative research because according to Peter Mahmud Marzuki, all research related to law (legal research) is always normative.

\section{RESULTS AND DISCUSSION}

The position of legal opinion (fatwa) of Indonesian Council of Ulama' (MUI) in statutory regulation system of Indonesia

Experts have different interpretations of statutory regulations. According to Bagir Manan, statutory regulations are written decisions of the state or government which contain guidelines or patterns of behavior that are generally binding in nature. ${ }^{9}$ Maria Farida Indrati suggests the term legislation (wetgeving or gesetzgebung) has two different meanings, namely:

a. Legislation is the process of forming state regulations, both at the central and regional levels;

b. Legislation is all state regulations which are the result of the formation of regulations, both at the central and regional levels. $^{10}$

${ }^{8}$ Sirman Dahwal, Pelaksanaan Perkawinan

Beda Agama (Studi Berbagai Kasus Di Indonesia

Priode Tahun 1986-2010), Jurnal Ilmu Hukum

Bengkoelen Justice, Program Pasca Sarjana Ilmu

Hukum vol.2. No.2.2012, p.464-465.

${ }^{9}$ Bagir manan, Dasar-Dasar PerundangUndangan Indonesia, Ind-Hill-Co, Jakarta, 1992, p.18.

${ }^{10}$ Maria Farida Indrati Soeprapto,Op.,Cit, p 3
Based on the definition above, laws and regulations are a collection of general and abstract legal norms. The formation of general and abstract legal norms that are written in nature is based on several things including:

1. The formation under the 1945 Constitution;

2. The formation is considered necessary because of legal necessity. ${ }^{11}$

Making rules in a country is part of the development of a legal system. Besides the application and enforcement of law and understanding of the law, making rules is one of the processes in the component of legal development (Astomo, 2018). ${ }^{12}$

Legislation in Indonesia has been regulated in Law No. 12 of 2011 on Making Rules which was later amended by Law No. 15 of 2019 . Making rules includes several principles in it. According to A. Hamid S. as quoted by Mukhlis Taib, there are at least three principles as the following:

1. The ideal of Indonesian law, Pancasila;
11 Jimly Asshiddiqie, Perihal UndangUndang, PT Raja Grafindo Persada, Depok, 2017, p. 179

${ }_{12}$ Putera Astomo,ilmu PerundangUndangan Teori Dan Praktek Di Indonesia, PT Raja Grafindo Persada, Depo, 2018, p. 71 
2. State principles based on law and principles of government following the constitutional system;

3. Other principles. ${ }^{13}$

In addition to the three principles above, according to A. Rosyid Al Atok, making rules should consider the following principles:

1. Principle of clear purpose;

2. Principle of arrangement;

3. Principle of proper agency and contents;

4. Principle of applicableness

5. Principle of visibility;

6. Principle of equality position in law;

7. Principle of legal certainty;

8. Principle of law enforcement according to individual circumstances ${ }^{14}$

The types of legislation in the Hierarchy of Rules is regulated in Article 7 point (1) of Law No. 15 of 2019 on the Amenmend of Law No. 12 of 2011 on Making Rules (hereinafter referred to as $U U$ Pembentukan Peraturan Perundang-undangan). Those types of legislation consist of:

13 Mukhlis Taib, Dinamika Perundangundangan Di Indonesia, Refika Aditama,Bandung, 2017, p.65

14 A. Rosyid Al Atok, Konsep Pembentukan Peraturan Perundang-Undangan, Setara Pers, Malang, 2015, p. 27 a. Constitution of the Republic of Indonesia of 1945;

b. People's Consultative Council Decree;

c. Law/Government Regulation In Lieu of Law;

d. Government Regulation;

e. Presidential Regulation;

f. Province Regulation; and

g. Regency/Municipality Regulation.

Article 8 point (1) of UU Pembentukan Peraturan Perundangundangan also states "Other kinds of Rules than as intended in Article 7 paragraph (1) covers the regulations stipulated by the People's Consultative Agency, House of Representatives, Regional Representatives Council, the Supreme Court, the Constitutional Court, the State Audit Board, the Judicial Commission, Bank of Indonesia, the Minister, agency, institution, or same level commission established by Law or Government on the instruction of Law, Provincial Regional House of Representatives, Governor, Regency/Municipality Regional House of Representatives, Regent/Municipal Government, the Village Head or the equivalent."

The state and the constitution are two institutions that cannot be separated from one another and are 
related to each other. The science of legislation is very important, especially in the framework of the formation of a national legal system, because all life, be it state life, national life or social life must be based on law. Laws and Регpu have functions in the legal system of a country. Those functions are as follows:

1) further regulation on the provision of Constitution of the Republic of Indonesia of 1945;

2) instruction of the Law will be governed by Law;

3) ratification of certain international agreements;

4) follow-up to the decision of the Constitutional Court; and/or

5) fulfill the legal needs of the people. $^{15}$

Based on Article 7, of Law No. 15 of 2019 on Amendment to Law No. 12 of 2011 on Making rules, the Hierarchy of Rules are as follows:

a. House of Representatives (DPR);

b. Province Regional House of Representative (DPRD);

c. President.

Based on this order, the President of the Republic of Indonesia holds governmental power according to the 1945 Constitution. The rights are as the following:

15 Ahmad Redi, Hukum Pembentukan Peraturan Perundang-Undangan, Sinar Grafika, Jakarta, 2018, p. 103
1) Submit a legal plan to DPR;

2) Set government regulations to carry out the law as it should. 16

Fatwas issued by MUI in the legal system in Indonesia need a deeper and more comprehensive study due to the existence of several fatwas that have caused controversy among the public. One of them is the MUI fatwa related to Ahok's statement on surah al-Maidah verse 51. Ahok who at that time served as the incumbent candidate for the Governor of Jakarta election must deal with the law and became the defendant since his statement of Koran as a means of lying considered an act of insulting religion. In the legal process, the police apparatus used the fatwa as a reference to turn Ahok a suspect.

The position of the fatwa institution is very important in Islam because the fatwas coming from the council of ulama' are onee of the solutions to solve the problems and differences that occur among Muslims. On the other hand, fatwas can also be used as a guide for Muslims in carrying out a religious obligation imposed on Muslims. However, in the structure of state institutions and the structure of Indonesian law, fatwas are not

16 Soimin, Pembentukan PerundangUndangan Negara Di Indonesia, UII PERS, Yogyakarta, 2010, p. 89 
included in the Indonesian statutory regulation system.

The followings are the fatwas that are not included in the Indonesian legal system as stated in Article 1 point (2) of Law No. 15 of 2019 on the Amendment to Law No. 12 of 2011 on Making Rules:

Rules are written regulations that contain legal norms binding in general and formed or determined by a state agency or official authorized by the procedures specified in the Rules.

Based on the article, MUI fatwas are not of statutory regulation that has binding legal force because MUI fatwas are not formed and stipulated by a state institution or authorized official as stated in Law No. 15 of 2019 on Amendment to the Law No. 12 of 2011 on Making Rules. MUI fatwas are basically non-binding and cannot be enforced by law enforcers, however, fatwas are only legal opinions that can be followed and may not be followed. Likewise, under the point of view of abstract regulations, fatwas can only be binding when a certain legal form has been established by a competent institution so that it becomes positive laws. Implementing fatwas as a form of personal religious awareness, not as a legal obligation means that the MUI fatwas are not a state law that have sovereignty that can be imposed on all the people. In fact, the legality of MUI fatwas cannot force Muslims to obey.

A reference based on fatwas, according to the author's analysis, is the same as referring to an expert's opinion, which means that fatwas do not act as positive law but only as material for consideration in the application of the law. Fatwas in Indonesia are not binding and do not have permanent legal force, this is because they are not included in the statutory regulation system. However, in certain cases, fatwas can have legal force when they are absorbed in existing legislation or supported by the law, and one example is the fatwa related to banking and Islamic financing. Sociologically and juridically, it can be concluded that the DSN-MUI fatwa is a non-binding set of rules and there is no legal compulsion for the subject of issuing a fatwa to comply with its provisions. Though on the other hand, based on the prevailing laws and regulations, there is an obligation for the regulator (Bank Indonesia) to ensure the contents of the DSN-MUI fatwa absorbed and transformed into sharia principles in the content of the legislation.

The implementation of fatwas in sharia banking law and other related laws does not mean they are included in the Indonesian legal system. Therefore, the MUI fatwas in Indonesia are not included 
in the statutory regulation system or the structure of state institutions. Moreover, in the state institutional structure, there is not an institution called mufti or fatwa institutions because the nature of the fatwas that stands as a non-binding legal opinion is different from the legal decision (qadha) produced by a judge.

Fatwas issued by MUI do not have permanent legal force because they are not included in the hierarchy of laws contained in Article 7 point (1) of Law No. 15 of 2019 on Amendment to Law No. 12 of 2011 on Making Rules. In the law, the hierarchy or legal system in Indonesia originates from the 1945 Constitution of the Republic of Indonesia, the MPR decrees as well as other laws and regulations which are all formed by State institutions that are given authority and power based on the 1945 Constitution and statutory regulations and government regulations in their position as a State institution.

Based on this, if analyzed using statutory theory as the guidance of analysis in this research, as mentioned by Hans Kelsen in his book 'General Theory of Law and State': a translation of the general theory of law and state described by Jimly Assihiddiqie in 'Hans Kelsen's Theories on Law', analyzing law should be as a dynamic character of a system of norms and functions of basic norms.
Therefore, for a legal norm to be valid, it must be determined by a higher one hierarchically as a norm is in a way determined by the constitution as the formation of law. Based on Hans Kelsen's opinion, it is clear that fatwas cannot be used as valid legal norms in the Indonesian statutory regulation system because they are not included in the hierarchy of laws and regulations as stated in Article 7 point (1) of Law No. 15 of 2019 on Amendment to Law No. 12 of 2011 on Making Rules.

This is in line with the principle of the rule of law theory which states that laws are formed and abolished by institutions or organs that have the authority to form them and based on higher norms. Thus a lower norm (inferior) can be formed based on a higher norm (superior), this shows that the law becomes hierarchical and layered so that it forms a hierarchy.

Therefore, fatwas are not included in the Indonesian statutory regulation system, and MUI is not included in the structure of state institutions in Indonesia according to the author's analysis. Moreover, it is following the Indonesian government system which annuls Islamic sharia instead of including it in a legal system. Islamic law is just considered as a source of law. 
Based on the description above, it can be concluded that the MUI fatwas are not included in the positive law or in the statutory regulation system that applies in Indonesia based on Law No. 15 of 2019 on Amendment to Law No. 12 of 2011 on Making Rules. Fatwas do not have permanent legal force, so they cannot be applied legally to all Indonesian people. Besides, MUI fatwas cannot be the legal instrument to enforce legal act or become the basis for imposing criminal sanctions for those who violate the law. The MUI fatwa can only become positive law if the substance is stipulated by the authorized state institution to become laws and regulations as stated and has been stated in Law No. 15 of 2019 on Amendment to Law No. 12 of 2011 on Making Rules.

\section{CLOSING}

\section{Conclusion}

MUI fatwas are not included in the positive law or in the statutory that applies in Indonesia based on Law No. 15 of 2019 on Amendment to Law No. 12 of 2011 on Making Rules. Fatwas do not have permanent legal force, so they cannot be applied legally to all Indonesian people. Besides, MUI fatwas cannot be the legal instrument to enforce legal act or become the basis for imposing criminal sanctions for those who violate the law. The MUI fatwas can only become positive law if the substance is stipulated by the authorized state institution to become laws and regulations as stated and has been stated in Law No. 15 of 2019 on Amendment to Law No. 12 of 2011 on Making Rules.

\section{Suggestion}

1) MUI Should issue fatwas that do not cause controversy in society and be more focused on the enforcement of Islamic law and the implementation of good Islamic law in society.

2) There should be special arrangements made by the government regarding the power of fatwas issued by MUI so that they are not issued for wasting and have the binding power and authority of law for Muslims. 


\section{REFERENCES}

\section{Books}

Ahmad Redi, Hukum Pembentukan Peraturan Perundang-Undangan, Sinar Grafika, Jakarta, 2018

Amrullah Ahmad, Dimensi Hukum Islam Dalam Sistem Hukum Nasional, Gema Insani Pers, Jakarta, 1996

Ahyar A. Gayo," Kedudukan Fatwa MUI Dalam Upaya Mendorong Pelaksanaan Ekonomi Syariah", Penelitian Hukum Badan Pembinaan Hukum Nasional Kementerian Hukum Dan HAM Ri, 2011

A. Rosyid Al Atok, Konsep Pembentukan Peraturan Perundang-Undangan, Setara Pers, Malang, 2015,

Bagir manan, Dasar-Dasar PerundangUndangan Indonesia, Ind-Hill-Co, Jakarta, 1992

Jimly Asshiddiqie, Perihal Undang-Undang, PT RajaGrafindo Persada, Depok, 2017

Ma'ruf Amin, dkk, Himpunan Fatwa Majelis Ulama Indonesia Sejak 1975, Erlangga, Jakarta, 2011

Mukhlis Taib, Dinamika Perundangundangan Di Indonesia, Refika Aditama, Bandung, 2017,

Putera Astomo, ilmu Perundang-Undangan Teori Dan Praktek Di Indonesia, PT RajaGrafindo Persada, Depo, 2018
Rachmat Trijono, Dasar-Dasar Ilmu Pengetahuan Perundang-Undangan, Papas Sinar Sinanti, Jakarta, 2014

Soimin, Pembentukan Perundang-Undangan Negara Di Indonesia, UII PERS, Yogyakarta, 2010,

Yusuf Qardhawi, Fatwa Antara Ketelitian Dan Kecerobohan, Gema Insani Press, Jakarta, 1997

Erfan Riadi, Kedudukan Fatwa Ditinjau Dari Hukum Islam Dan Hukum Positif (Analisis Yuridis Normatif),

\section{$\underline{\text { Journals }}$}

Jurnal Hukum http://ejournal.umm.ac.id/index.php/ulu $\mathrm{m} /$ article/viewFile/1305/1398, retrieved on $20^{\text {th }}$ of January 2019

Isa Ansori, Kedudukan Fatwa Di Beberapa Negara Muslim (Malaysia, Brunei Darussalam Dan Mesir), Jurnal hukum, http://ejournal.radenintan.ac.id/index.p hp/analisis/article/view/1790, retrieved on $10^{\text {th }}$ of October 2019 at 1 PM

Noname Kedudukan Lembaga Fatwa Mesir" http://dar-alifta.org/Module.

aspx ? Name $=$ aboutdar $\left(\right.$ retrieved on $10^{\text {th }}$ of October 2019)

Sirman Dahwal, Pelaksanaan Perkawinan Beda Agama (Studi Berbagai Kasus Di Indonesia Priode Tahun 1986-2010), Jurnal Ilmu Hukum Bengkoelen Justice, Program Pasca Sarjana Ilmu Hukum vol.2.No.2.2012, p.464-465. 